\title{
Allergen specific immunotherapy enhanced defense against bacteria via TGF- $\beta 1$-induced CYP27B1 in asthma
}

\author{
Junyi Wang ${ }^{1,5, *}$, Xiaoyu Liu ${ }^{2, *}$, Hui Wang ${ }^{2}$, Yin $\mathrm{Li}^{3}$, Nan Lan ${ }^{1}$, Xiefang Yuan ${ }^{1}$, Min \\ Wu ${ }^{4}$, Zhigang Li ${ }^{1,2}$ and Guoping Li ${ }^{1,5}$ \\ ${ }^{1}$ Inflammation \& Allergic Diseases Research Unit, Affiliated Hospital of Southwest Medical University, Luzhou 646000, China \\ ${ }^{2}$ The State Key Laboratory of Respiratory Disease for Allergy at Shenzhen University, Shenzhen University School of Medicine, \\ Shenzhen 518060, China \\ ${ }^{3}$ The First Clinic College, Chongqing Medical University, Chongqing 401331, China \\ ${ }^{4}$ Department of Biomedical Sciences, University of North Dakota, Grand Forks, North Dakota 58203, United States of America \\ ${ }^{5}$ Department of Respiratory Disease, the Third People's Hospital of Chengdu, Chengdu 610031, China \\ "These authors have contributed equally to this work \\ Correspondence to: Guoping Li, email: Izlgp@163.com \\ Zhigang Liu, email: Izg@szu.edu.cn \\ Keywords: asthma, specific immunotherapy, innate immunity, cathelicidin, TGF- $\beta$ \\ Received: May 04, $2017 \quad$ Accepted: June 29, $2017 \quad$ Published: August 02, 2017 \\ Copyright: Wang et al. This is an open-access article distributed under the terms of the Creative Commons Attribution License 3.0 \\ (CC BY 3.0), which permits unrestricted use, distribution, and reproduction in any medium, provided the original author and source \\ are credited.
}

\section{ABSTRACT}

Allergen specific immunotherapy (SIT) is the only specific treatment of allergic diseases at present. How SIT impacts pulmonary innate immunity against bacteria currently remains unclear. In this study, dust mite extracts (HDM)-sensitized mice were immunized with a subcutaneous injection of HDM. These mice were then challenged with an intranasal administration of HDM. After the last challenge, mice were infected with an intranasal instillation with $P$. aeruginosa ( $P$.a). We measured the score of tissue inflammation, the expression of cathelicidin-related antimicrobial peptide (CRAMP) and 25-Hydroxyvitamin D-1Alpha-hydroxylase (CYP27B1) in lung. We analyzed the effect of TGF- $\beta 1$ on CRAMP and CYP27B1 in airway cells (16HBE), and investigate the role of TGF- $\beta 1$-induced CYP27B1 in defense against bacteria in 16HBE cell. We found that SIT attenuates HDM-induced airway inflammation and airway responsiveness (AHR), which is involved in the increased levels of HDM-specific IgG2a, IL-10, TGF- $\beta 1$, IFN- $Y$, CRAMP and CYP27B1. SIT ameliorates pulmonary infectious inflammation associated with an improving defense of HDM-challenged mice against $P$. aeruginosa. Meanwhile, TGF- $\beta 1$ significantly increased the expression of CYP27B1 in a dose-dependent manner. TGF- $\beta 1$ did not increase the levels of CRAMP in airway epithelial cells. Furthermore, 25-dihydroxyvitamin $D 3\left(25 V^{2}\right)$ is required for TGF$\beta 1$-induced CRAMP in airway epithelial cells. CRAMP was significantly increased in TGF- $\beta 1 / 25 V_{3}$-treated $16 \mathrm{HBE}$ cells. These findings illustrated that TGF- $\beta 1$ is a major player against bacterial infections in SIT models via induction of CYP27B1 rather than CRAMP. Collectively, these findings highlight a role for SIT enhancing host defense against bacteria depending on TGF- $\beta 1$-induced CYP27B1in asthma. 


\section{INTRODUCTION}

Asthma is a chronic airway inflammation disease and represents a significant health problem worldwide [1]. Airway colonization of potentially pathogenic microorganisms in asthma is associated with severe airway obstruction, neutrophilic airway inflammation, and decreased responses to current asthma therapies [2]. Bronchial asthma can weaken innate immunity of the airway, therefore increasing the risk of lung infection [3]. In turn, bacterial infection can also aggravate bronchial asthma ${ }^{2}$. However, immune responses to airborne pathogens, such as bacteria, may contribute to resistance to allergic responses [4]. The relationship between asthma and pathogenic infection remains unclear.

Regular administration of inhaled corticosteroids (ICS) is associated with an increased risk of oropharyngeal colonization with streptococcus pneumoniae in children with asthma [5]. Our previous studies showed that inhaled budesonide suppressed pulmonary anti-bacterial defense through down-regulation of CRAMP (also named LL-37 and CAMP in human) [6], which is a critical antimicrobial peptide (AMP) for host defense. In addition, our previous studies also showed severe asthma exacerbation with vitamin D3 ( $\left.\mathrm{VD}_{3}\right)$-deficiency showed lower forced expiratory volume in one second (FEV1) with the phenotype of neutrophilic inflammation [7]. As the active form of $\mathrm{VD}_{3}, 1,25 \mathrm{VD}_{3}$ can bind to vitamin $\mathrm{D}$ receptorspecifically form vitamin D response elements (VDREs), and therefore modulates the expression of cathelicidin [8]. Recent studies have demonstrated that conversion of precursor $25 \mathrm{VD}_{3}$ to active $1,25 \mathrm{VD}_{3}$ via vitamin D-activating enzyme CYP27B1 can stimulate expression of antibacterial CRAMP $[9,10]$. Toll-like receptor (TLR) 2/1 ligand-induced CRAMP was positively associated with percent change in $25 \mathrm{VD}_{3}$. Intracrine conversion of precursor $25 \mathrm{VD}_{3}$ to active $1,25 \mathrm{VD}_{3}$ can promote the expression of CRAMP [10].

House dust mites (HDM) are the most important inhalant allergens and nearly $80 \%$ of asthma patients were sensitized to their allergens [11]. SIT is the only effective treatment for changing the natural course of allergic disease [12]. The mechanism of SIT remains unclear. Previous studies found that mice immunized with chlamydial major outer membrane protein mixed with cholera toxin and $\mathrm{CpG}$ oligodeoxynucleotide adjuvants induced a protection against respiratory challenge with Chlamydia, which was correlated with IFN- $\gamma$ production [13]. SIT contributes to immune tolerance and long-term changes in the immune system by inducing regulatory $\mathrm{T}$ (Treg) cells and Th1 immune response [14]. However, the effect of HDMimmunotherapy on innate immunity against lung infection in asthma remains unresolved. In the current study, we evaluated the impact of HDM-immunotherapy in defense against bacteria. We show that SIT improved the defense of HDM-challenged mice against $P$. aeruginosa depending on TGF- $\beta 1$-induced CYP27B1. We further find that $25 \mathrm{VD}_{3}$ is required for TGF- $\beta 1$ induced CRAMP.

\section{RESULTS}

\section{SIT attenuates HDM-induced airway inflammation}

To evaluate the impact of SIT in allergen-induced airway inflammation, HDM-sensitized mice received an immunotherapy using a subcutaneous injection of HDM (Figure 1A). The mice were then challenged by intranasal HDM instillations. The total number of cells and the number of inflammatory cells including eosinophils, neutrophils and lymphocytes in the BAL fluid were decreased in the HDM-treated mice (SIT) compared to the HDM-sensitized and challenged mice (HDM) (Figure 1B). The total number of cells showed a 51.2 percent decrease, and eosinophils showed a 63.6 percent decrease in SIT mice compared to HDM mice (Figure 1B, $p<0.001$ and $p<0.001$, respectively). Inflammatory cell infiltration into airways and alveoli was decreased in SIT mice compared to HDM mice (Figure 1C). The scores of cellular infiltration into the lungs were also significantly decreased in SIT mice compared to HDM mice (Figure $1 \mathrm{D}, \mathrm{P}<0.05)$. These data showed that SIT decreased HDMinduced airway inflammation.

\section{SIT attenuates AHR associated with increased HDM-specific IgG2a}

Previous studies have shown that AHR were strongly reduced upon ovalbumin (OVA)- immunotherapy [15]. To further investigate effect of HDM-immunotherapy on lung function in HDM mice, we measured airway responsiveness to methacholine challenges by using Buxco whole-body plethysmography system. HDM mice challenged with methacholine demonstrated methacholine dose-dependent increases in Penh levels, which were significantly reduced in SIT mice compared to HDM mice (Figure 2A, $\mathrm{p}<0.001$ ). Having confirmed that induced IgG4 seems to suppress IgE levels, which was associated with treatment efficacy in allergic patients receiving subcutaneous immunotherapy [16]. SIT selectively removed long-lived IgE antibodies on mast cells [17]. To assess the effect of SIT in levels of antibodies to HDM, HDM-specific antibodies were measured. The HDM-specific IgE and IgG1 levels showed 51.3\% and 12.5\% decrease in SIT mice compared to HDM mice, respectively (Figure 2B, $\mathrm{p}<0.001$; Figure 2C, $\mathrm{p}<0.001$ ). By contrast, the HDM-specific IgG2a level showed a 1.86-fold increase in SIT mice compared to HDM mice (Figure 2D, $\mathrm{p}<0.001$ ). These findings indicated that AHR was strongly reduced upon SIT, which was associated with increased HDMspecific IgG2a, but decreased HDM-specific IgE and IgG1. 


\section{SIT increases the levels of IL-10, TGF- $\beta 1$, and IFN- $\gamma$}

Previous studies showed that immunotherapy ameliorated airway inflammation via IL-10 in a chronic asthma model [18]. IL-10 and TGF- $\beta 1$ produced by functional Treg cells are now well established during immunotherapy [19]. We observed a robust decrease of IL-4 in SIT mice compared to the HDM mice (Figure $3 \mathrm{~A}, \mathrm{p}<0.001)$. By contrast, the levels of IL-10, IFN- $\gamma$ and TGF- $\beta 1$ showed 1.48-fold, 1.57-fold and 1.41fold increase in SIT mice compared to the HDM mice, respectively (Figure $3 \mathrm{~B}, \mathrm{p}<0.001$; Figure $3 \mathrm{C}, \mathrm{p}<0.001$; Figure 3D, $\mathrm{p}<0.001)$. These findings suggest that SIT increased the levels of IL-10, TGF- $\beta 1$, and IFN- $\gamma$, while decreased IL-4 in HDM-induced airway inflammation.

\section{SIT increases the expression of CRAMP and CYP27B1 in lung}

Allergic individuals are more susceptible to respiratory tract infections due to an impaired antimicrobial defense, and SIT upregulates the levels of human $\beta$-defensins in patients with seasonal allergic rhinitis $[16,17]$. To further investigate whether SIT improved cathelicidin (CRAMP) in HDM mice, we measured CRAMP in lungs and BALF. As seen in Figure 4A, PBS control mice showed a predominant expression of CRAMP in airway epithelium, which were significantly reduced in HDM mice. By contrast, SIT with HDM resulted in an increased expression of CRAMP in airway epithelium. To examine the transcript levels of CRAMP genes, real-time-PCR was utilized to detect the mRNA levels of CRAMP in lung tissue. The CRAMP transcription level showed a $42 \%$ decrease in HDM mice compared to PBS control mice (Figure 4B, $\mathrm{p}<0.05$ ). As compared with HDM-exposed mice, the CRAMP transcript level showed a 2.18 -fold increase in SIT mice (Figure 4B, $\mathrm{p}<0.001$ ). In addition, we found that CRAMP protein production in BALF showed a $57 \%$ decrease in HDM mice as compared with PBS control mice (Figure 4C, $p<0.001$ ). Meanwhile, the CRAMP production in BAL fluid showed a 2.16-fold increase in SIT mice compared to HDM mice (Figure 4C, $\mathrm{p}<0.001$ ). We further analyzed the expression of CYP27B1 in the lung with immunohistochemistry and real-time PCR.
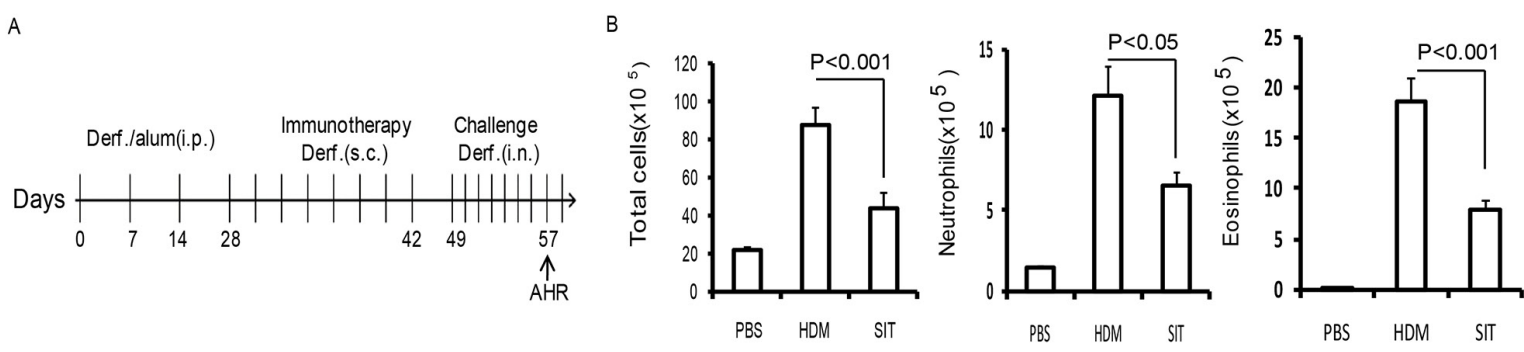

C
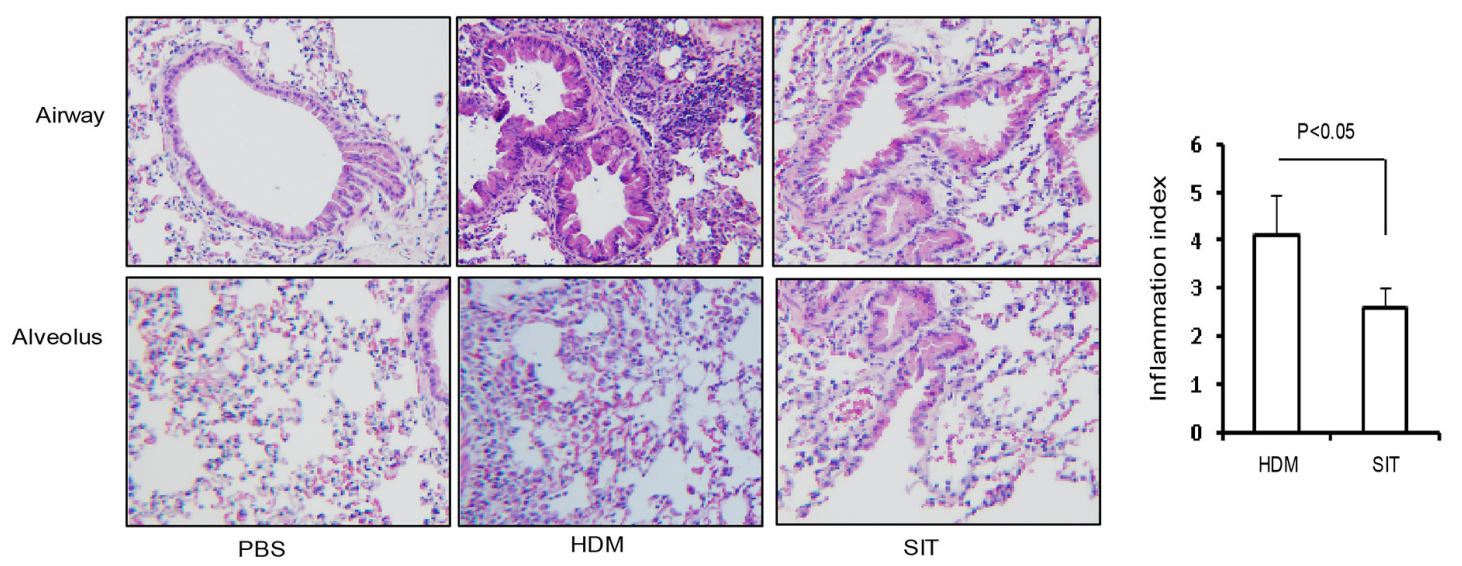

Figure 1: HDM-immunotherapy attenuates HDM-induced airway inflammation. (A) HDM-specific immunotherapy protocol for HDM- inducing asthmatic mice ( $\mathrm{n}=8$ mice for each group). (B) Total number of inflammatory cells as well as eosinophils, neutrophils and lymphocytes in the BAL of mice were determined by differential cell analysis. (C) Lung tissues were stained using H\&E (original magnification, $\times 200$ ). (D) The inflammatory cell infiltration index was determined in the lungs in (C). One-way ANOVA for group comparisons. Significant differences in the mean values were defined as $p<0.05$. PBS mice indicated PBS control mice. SIT mice indicated HDM-immunotherapy mice. HDM mice indicated HDM-sensitized and challenged mice. 
As seen in Figure 4D, the expression of CYP27B1 protein in lungs was low in PBS mice and mice exposed to HDM. However, SIT predominantly increased the expression of CYP27B1 protein in lungs. We also evaluated CYP27B1 mRNA levels in whole lungs. In PBS control mice and HDM-exposed mice, CYP27B1 mRNA levels were low. CYP27B1 mRNA levels showed a 3.8-fold increase in SIT mice compared to HDM mice (Figure 4E, $\mathrm{p}<0.001$ ). Taken together, these findings suggested that SIT increased CRAMP gene transcript and protein production associated with the upregulation of CYP27B1 expression in mice.

\section{SIT ameliorates pulmonary infection inflammation}

Previous studies have implicated that allergic airway inflammation suppresses the innate antimicrobial

A

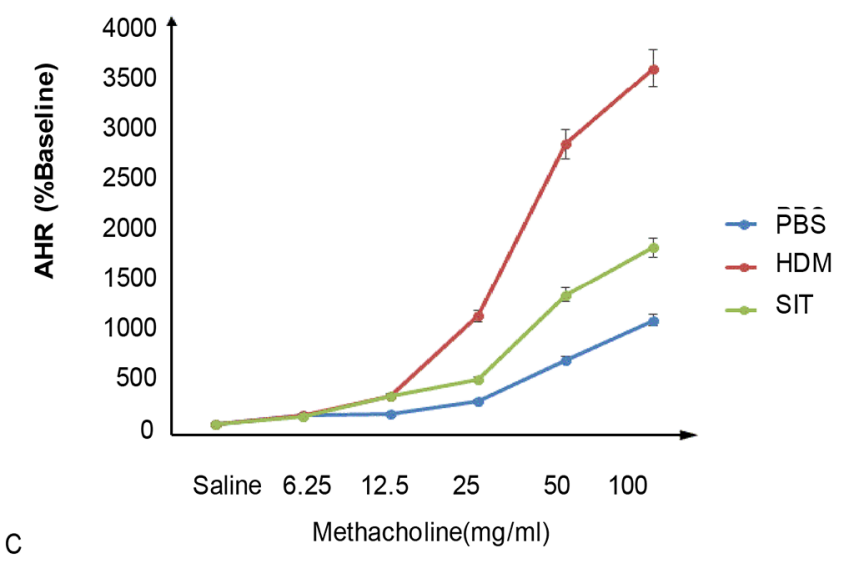

C

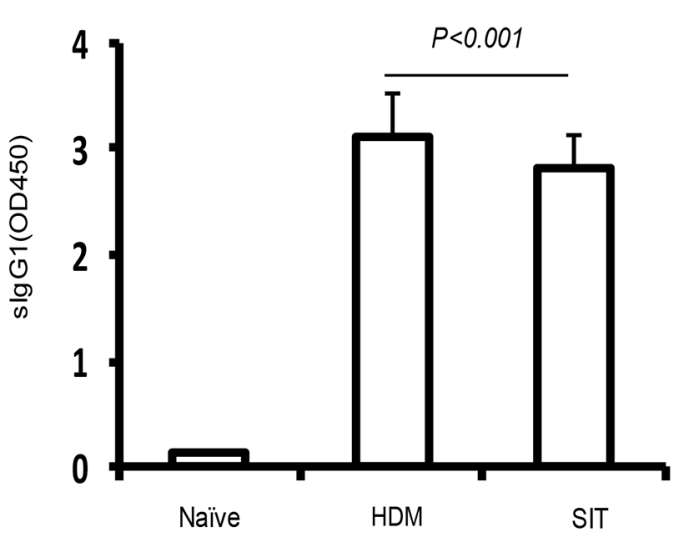

host defense [3]. However, whether SIT regulates innate antimicrobial host defense remains unclear. To investigate whether SIT improved host defense against bacteria, we evaluated inflammation responsiveness to $P$. aeruginosa infection in HDM-exposed mice. 24 hour after the last HDM challenge, temperature data were collected as part of routine monitoring for inflammation responsiveness to $P$. aeruginosa infection. All mice showed a marked increase in temperature at 24 hours after $P$. aeruginosa administration. HDMexposed mice showed a significant increase in temperature of $1.9^{\circ} \mathrm{C}$ after $P$. aeruginosa administration compared to PBS control mice. SIT mice showed a significant drop in temperature of $0.7^{\circ} \mathrm{C}$ compared to HDM mice (Figure 5A). Meanwhile, the total number of cells and neutrophils in the BALF predominantly decreased in SIT mice compared to the HDM mice after $P$. aeruginosa administration (Figure 5B). In addition, inflammatory cell infiltration into the airways and alveoli was determined by H\&E staining (Figure 5C).

B

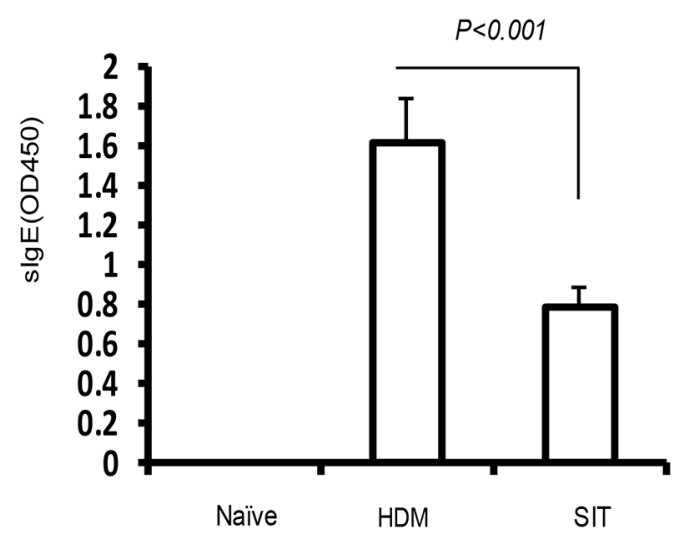

D

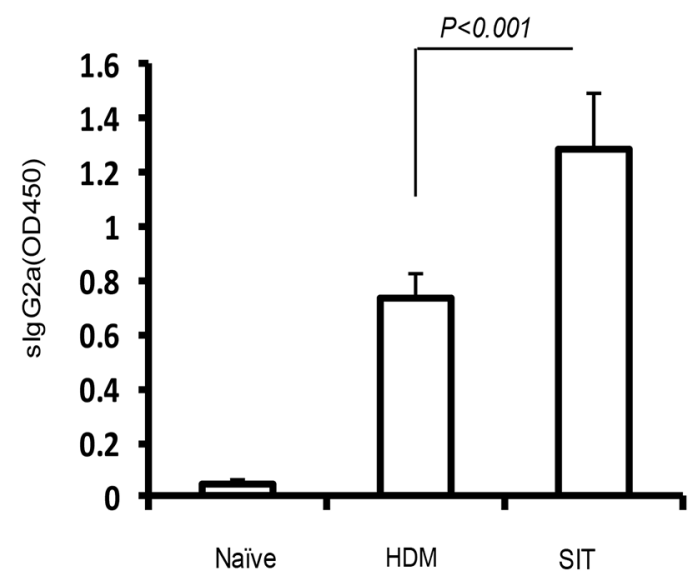

Figure 2: HDM-immunotherapy attenuates AHR and increased HDM-specific IgG2a (A) AHR was determined by measuring the enhanced pause (Penh) ( $\mathrm{n}=8$ each group). Serum levels of allergen-specific (B) IgE, (C) IgG1 and (D) IgG2a were measured by ELISA as optical density (OD). Data were shown as means \pm SDEV $(n=8)$. One-way ANOVA for group comparisons. Significant differences in the mean values were defined as $\mathrm{p}<0.05$. 
All mice showed a marked cellular infiltration into the lungs at 24 hours after $P$. aeruginosa administration compared to PBS control mice. The scores of inflammatory cell infiltration into the lungs showed a 51.7 percent decrease in SIT mice compared to the HDM mice after $P$. aeruginosa administration (Figure 5D, $\mathrm{P}<0.05$ ). These findings indicate that SIT ameliorated pulmonary infection inflammatory response and inflammatory cell infiltration during HDM mice exposure to $P$. aeruginosa.

\section{SIT enhances defense against bacteria}

To determine whether HDM-immunotherapy can increase defense against bacteria, bacterial levels in BALF and lungs were determined at $24 \mathrm{~h}$ after mice exposure to $P$. aeruginosa. HDM-exposed mice showed lots of gram negative bacteria in BALF compared to PBS mice at 24 hours after $P$. aeruginosa administration. However, the number of gram negative bacteria showed a marked drop in BALF from SIT mice compared to HDM mice at 24 hours after $P$. aeruginosa administration (Figure 6A). The lung tissue of HDM mice showed a significantly increase in the number of CFU compared to PBS mice at 24 hours after $P$. aeruginosa administration (Figure 6B). The number of CFU showed a 69.4 percent decrease in lung from SIT mice compared to HDM mice at 24 hours after $P$. aeruginosa administration (Figure $6 \mathrm{C}, \mathrm{p}<0.001$ ). These data confirmed that SIT enhanced defense against bacteria during HDM- challenged mice exposure to P. aeruginosa.

\section{TGF- $\beta 1$ increases CRAMP depending CYP27B1 in $16 \mathrm{HBE}$ cells}

Based on our present findings that SIT with HDM associated with an increase of CRAMP and CYP27B1 in mice exposed to HDM, we analyzed the effect of TGF- $\beta 1$ on CRAMP and CYP27B1 in 16HBE cell lines. We observed no change in the levels of CRAMP in TGF$\beta 1$-treated 16HBE cells compared to PBS-treated 16HBE cells (Figure 7A, $\mathrm{p}>0.05$ ). 25VD $\mathrm{VD}_{3}$ increased the expression of CRAMP compared to PBS-treated 16HBE cells (Figure $7 \mathrm{~A}, \mathrm{p}<0.001)$. However, TGF- $\beta 1 / 25 \mathrm{VD}_{3}$ significantly

B

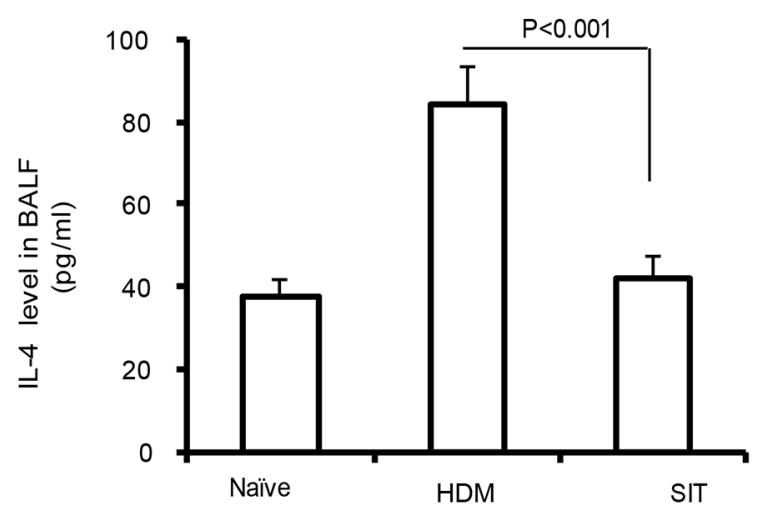

D

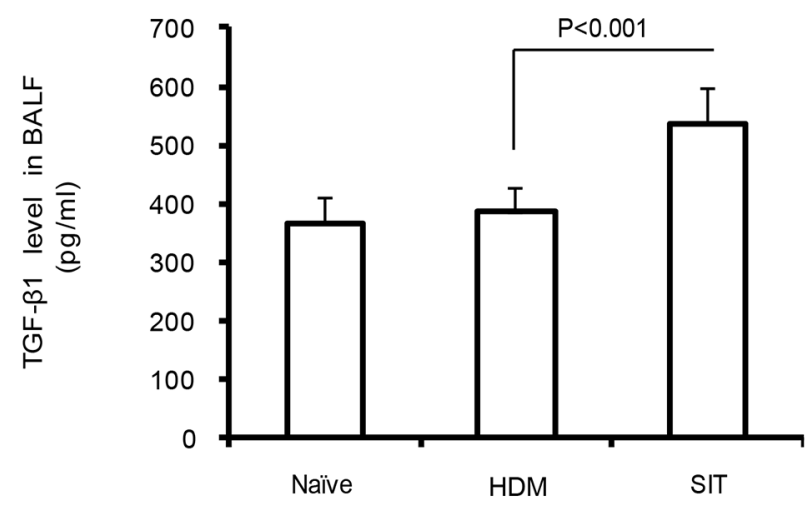

Figure 3: HDM-immunotherapy increases the levels of IL-10, TGF- $\boldsymbol{\beta} 1$, and IFN- $\boldsymbol{\gamma}$. Standard ELISA was performed to determine the levels of IL-10 (A), IL-4 (B), IFN- $\gamma$ (C), and TGF- $\beta 1$ (D) in BAL fluid. Data were shown as means \pm SDEV (n=8). One-way ANOVA for group comparisons. Significant differences in the mean values were defined as $\mathrm{p}<0.05$. 
increased the expression of CRAMP compared to $25 \mathrm{VD}_{3}$-treated 16HBE cells (Figure 7A, $\mathrm{p}<0.001$ ). The chemical inhibitor of $1 \alpha$-hydroxylase, ITRA, inhibited the expression of CRAMP compared to TGF$\beta 1 / 25 \mathrm{VD}_{3}$-treated $16 \mathrm{HBE}$ cells (Figure $7 \mathrm{~A}, \mathrm{p}<0.001$ ). Previous studies showed that CYP27B1 converts 25-hydroxyvitamin $\mathrm{D}_{3}$ into 1alpha, 25-dihydroxyvitamin $D_{3}$ [20]. To investigate the effect of TGF- $\beta 1$ on CYP27B1 in airway cells, $16 \mathrm{HBE}$ cells were stimulated with $0.1 \mathrm{ng}$, 1 ng and 10 ng TGF- $\beta 1$, respectively. TGF- $\beta 1$ significantly increased the expression of CYP27B1 in a dose-dependent manner (Figure 7B).

To examine the transcript levels of CRAMP genes, real time-PCR was utilized to detect the mRNA levels of CRAMP. $25 \mathrm{VD}_{3}$ increased the transcript levels of CRAMP compared to PBS-treated 16HBE cells (Figure $7 \mathrm{C}, \mathrm{p}<0.001$ ), but the transcript levels for CRAMP in TGF- $\beta 1$-treated $16 \mathrm{HBE}$ cells were unaltered, compared with PBS-treated 16HBE cells (Figure 7C, $\mathrm{p}>0.05$ ). It was interesting that the CRAMP transcript was significantly increased in TGF- $\beta 1 / 25 \mathrm{VD}_{3}$-treated $16 \mathrm{HBE}$ cells compared to $25 \mathrm{VD}_{3}$-treated $16 \mathrm{HBE}$ cells (Figure $7 \mathrm{C}, \mathrm{p}<0.001)$. The transcript levels of CYP27B1 was also an increased in a dose-dependent manner (Figure 7D). Taken together, these findings demonstrated that TGF- $\beta 1$ did not directly increase CRAMP expression, and CYP27B1 play a key role in TGF- $\beta 1$-induced CRAMP expression in vitro.
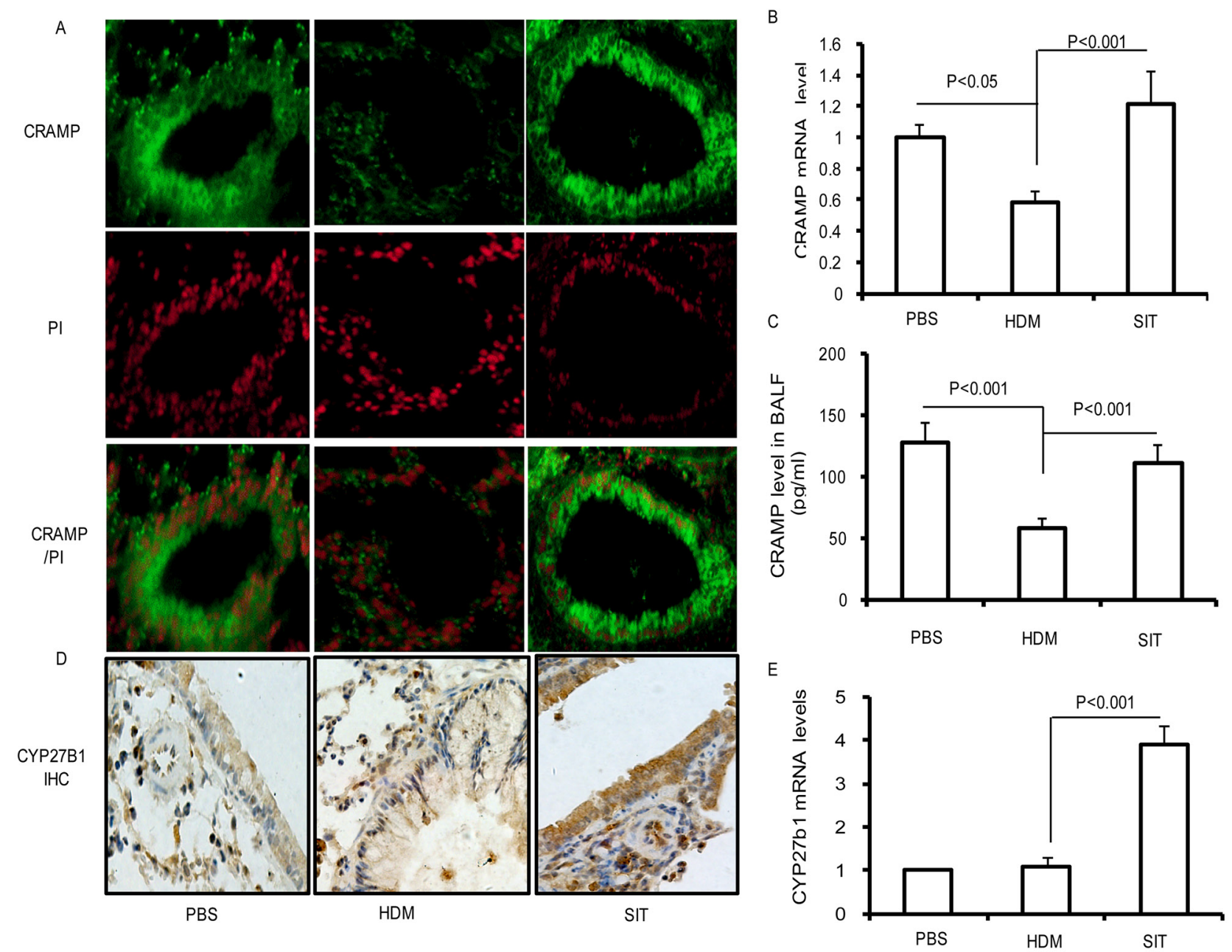

Figure 4: HDM-immunotherapy increases the expression of CRAMP and CYP27B1 in lung. (A) Frozen lung sections were stained with polyclonal antibodies against CRAMP followed by incubation with FITC-conjugated secondary antibody (green) or PI (red). Sections were observed using confocal microscopy (original magnification $\times 400$ ). Results are representative of three experiments. (B) The mRNA expression of CRAMP was determined in the lungs using Real-time-PCR. (C) Standard ELISA was performed to determine the levels of CRAMP levels in the BAL fluid. (D) Lung sections were stained with polyclonal antibodies against CYP27B1. Sections were observed using microscopy (original magnification $\times 200$ ). (E) The mRNA expression of CYP27B1 was determined in the lungs using Realtime-PCR. Data were shown as means \pm SDEV $(n=8)$. One-way ANOVA for group comparisons. Significant differences in the mean values were defined as $\mathrm{p}<0.05$. 


\section{TGF- $\beta 1$ increases host defense against bacteria by CYP27B1-dependent activation}

Our previous studies have confirmed that blocking CRAMP significantly increase bacterial CFUs [6]. To further investigate the effect of TGF- $\beta 1$ induced CYP27B1 in defense against bacteria in airway cells, $16 \mathrm{HBE}$ cells were pretreated with $25 \mathrm{VD}_{3}$, TGF- $\beta 1$, TGF $-\beta_{1} / 25$ VD3 followed by $P$. aeruginosa infection. The chemical inhibitor of ITRA was also used to explore the role of CYP27B1 in TGF- $\beta 1$ - treated $16 \mathrm{HBE}$ cells. We observed no change in the levels of CFUs in TGF- $\beta 1-$ treated 16HBE cells compared to PBS-treated 16HBE cells (Figure 8A, p>0.05). Meantime, CFUs were significantly decreased in TGF- $\beta 1 / 25 \mathrm{VD}_{3}$-treated $16 \mathrm{HBE}$ cells compared to $25 \mathrm{VD}_{3}$-treated $16 \mathrm{HBE}$ cells (Figure $7 \mathrm{~A}, \mathrm{p}<0.001)$. ITRA significantly increased the level of CFUs compared to TGF- $\beta 1 / 25 \mathrm{VD}_{3}$-treated $16 \mathrm{HBE}$ cells (Figure $7 \mathrm{~B}, \mathrm{p}<0.001$ ). These data indicated that TGF- $\beta 1$ increases defense against bacteria by CYP27B1-dependent activation. Figure $7 \mathrm{~F}$ illustrates a model in which the role of HDM immunotherapy enhances host defense against bacteria during allergic airway inflammation.

\section{DISCUSSION}

Th2 cell-mediated disorders were supposed to be the most important pathological phenomenon of allergic asthma, but it cannot fully explain the mechanism of allergic asthma. Allergen-specific immunotherapy remains as the only curative treatment. Some evidences have showed that SIT with HDM not only regulates Th2 immune response, but also modulates Treg cells [21]. The suppressor cytokines IL-10 and TGF- $\beta$ produced by functional Treg cells played a key role in the generation of immune tolerance to allergens [19]. Treg cells secrete TGF- $\beta 1$, which plays an important role in inhibiting allergic inflammation [22]. In our current research, an asthma mouse

A

B
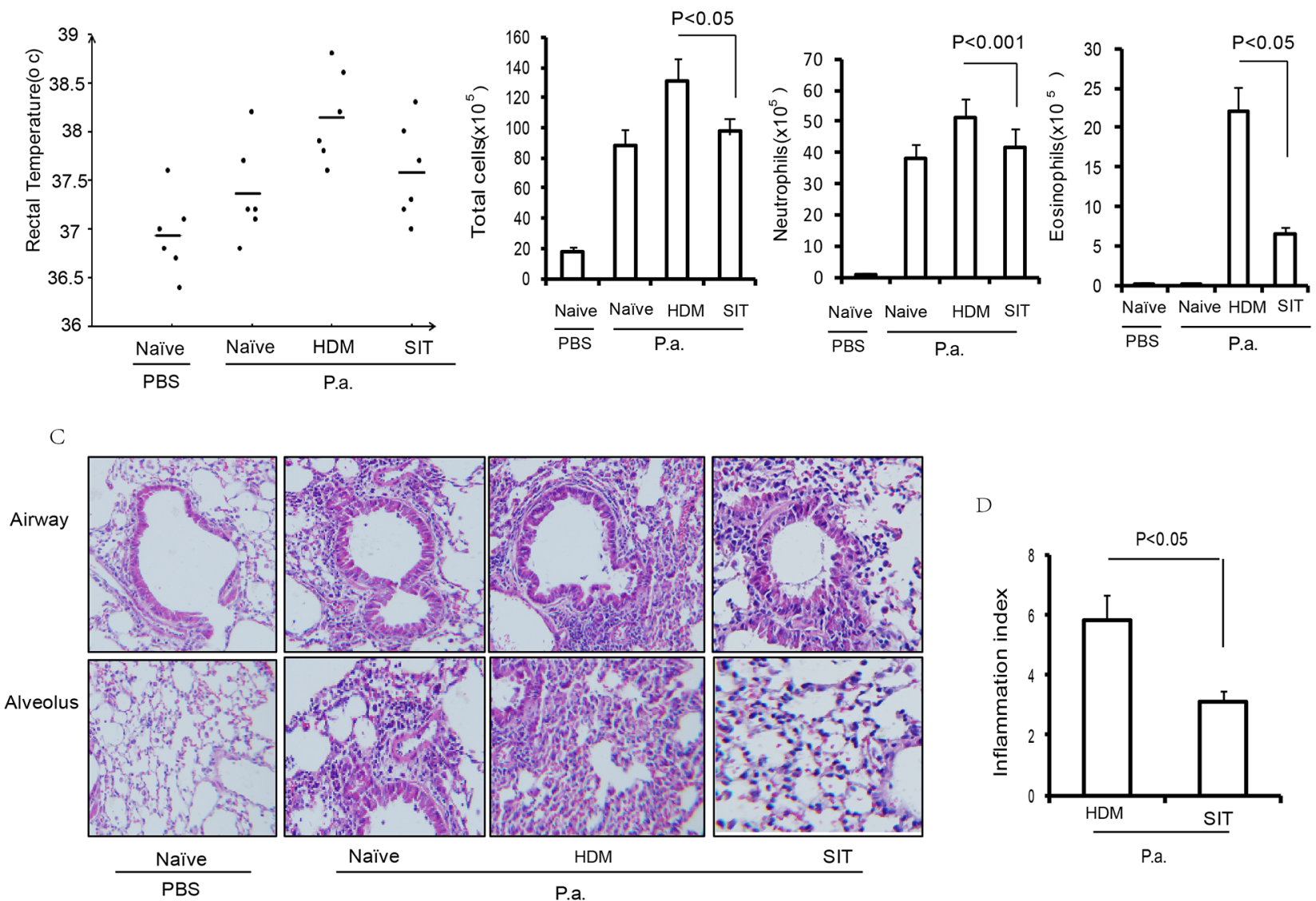

D

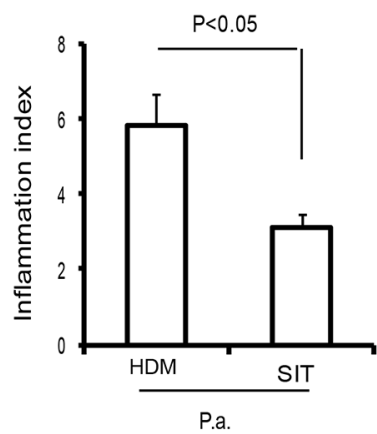

Figure 5: HDM-immunotherapy ameliorates pulmonary infection inflammation. (A) Rectal temperature was recorded as part of routine monitoring for inflammation responsiveness to $P$. aeruginosa infection. Data were shown as means $\pm \mathrm{SDEV}(\mathrm{n}=6)$. (B) The total number of inflammatory cells as well as eosinophils, neutrophils and lymphocytes in the BAL of mice were determined by differential cell analysis. (C) The lung tissues were stained using H\&E (original magnification, $\times 200$ ). (D) The inflammatory cell infiltration index was determined in the lungs in (C). One-way ANOVA for group comparisons. Significant differences in the mean values were defined as $p<0.05$. 
model was employed to detect the role of HDM-SIT. AHR of HDM-exposed mice significantly increased. The number of inflammatory cells in the BALF showed a significant increase, accompanied with more severe peribronchial and perivascular infiltration, higher IL-4 and IgE levels. HDMSIT mice exhibited decreased lung inflammation index and airway responsiveness. The phenotype was related to the changes of IL-4, IFN- $\gamma$ and IgE. Especially, Tregcytokines IL-10 and TGF- $\beta 1$ were upregulated significantly. Our experiments further confirmed that HDM-specific immunotherapy ameliorated AHR, lung inflammation and Th1/Th2 immune balance in asthma mice model, and modulated the function of Treg cells.

With low host defense against bacteria, allergic asthma patients may have increased risk of lung infection. Antibacterial peptides play an important role in innate immunity against bacteria [23]. In humans, the major classes of host defense peptides include defensins and cathelicidin [24]. CRAMP with broad spectrum microbicidal activities was expressed in airway epithelial cells, alveolar macrophages and bronchial glands, play important roles in the lung innate immune response [25]. Lung AMPs are major sentinels of innate immunity by preventing microbial colonization and infection. The bactericidal activity of AMPs against bacteria is compromised in patients with asthma [26]. Bacterial colonization was associated with initiating events of early asthma in young children with severe recurrent wheeze. Neonates colonized in the hypopharyngeal region with bacterial, are at increased risk for recurrent wheeze and asthma early in life [27]. In our present studies, the expression of CRAMP protein and mRNA in lungs was significantly reduced in HDMexposed mice. It was further confirmed that CRAMP with asthma was inhibited. Furthermore, our studies provide the first evidence that HDM-specific immunotherapy increased the expression of CRAMP during HDM-induced allergic airway inflammation mice.

Our findings showed that HDM-specific immunotherapy increased the level of IL-10, TGF- $\beta 1$, and IFN- $\gamma$, but was associated with low IL-4 in HDM-induced

A

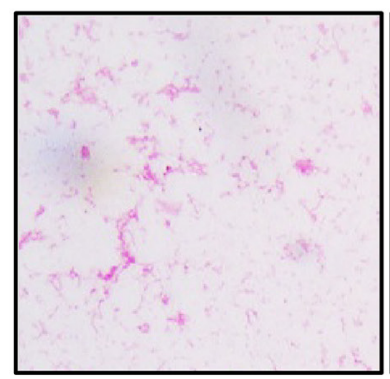

PBS

PBS

B

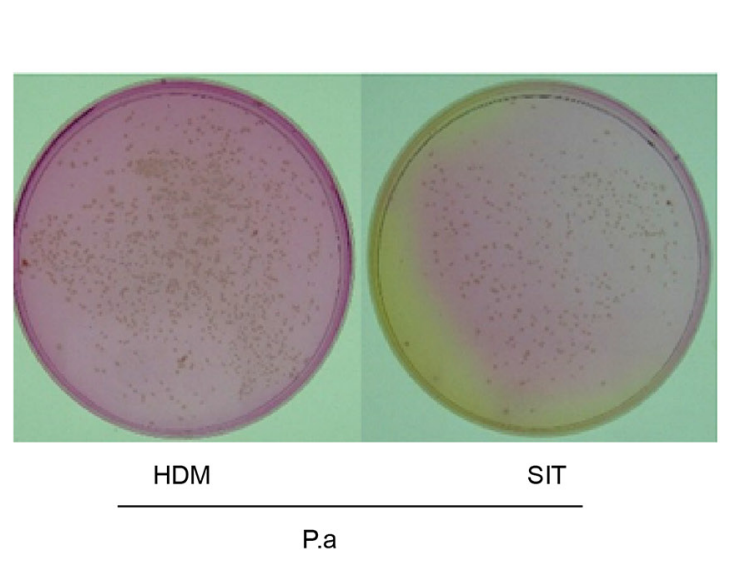

B

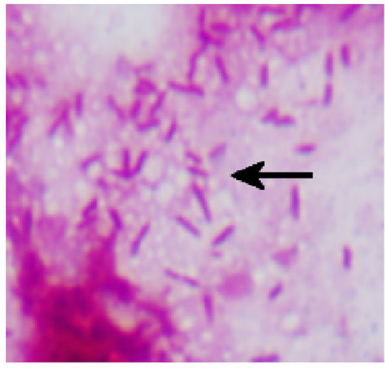

HDM

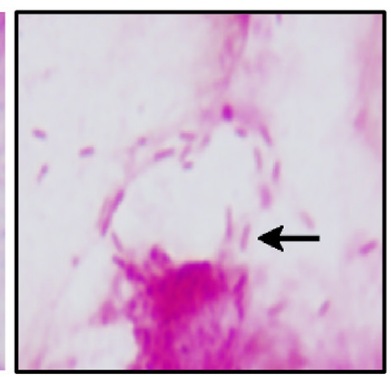

SIT c

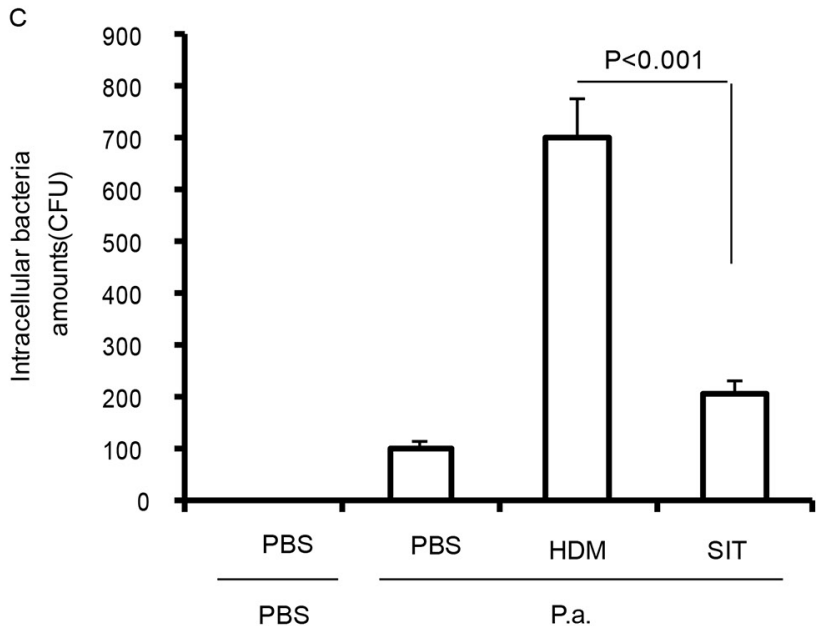

Figure 6: HDM-immunotherapy enhances defense against bacteria. (A) BAL fluid were stained using a Gram's Method. The slides were evaluated for bacteria infiltration under a light microscope (original magnification, $\times 200$ ). (B) Represents the bacterial colonies on agar plates. (C) Bacterial colonies were counted in lung homogenate suspension. Data were shown as means \pm SDEV ( $\mathrm{n}=6$ ). One-way ANOVA for group comparisons. Significant differences in the mean values were defined as $\mathrm{p}<0.05$. 
airway inflammation mice. It has been shown that Th2cytokines IL-4 and IL-13 reduced antibacterial peptides against bacteria $[2,28]$. IL-10 repressed the expression of anti-microbial peptide in atopic dermatitis [29]. Previous studies have also confirmed that IL-33 enhanced antimicrobial defense against skin bacterial infection via promoting antimicrobial capacity of dermal macrophages [30]. This cytokines, such as IL-17 and IL-22, induced antimicrobial proteins and neutrophil chemoattractants [31]. However, some studies showed that Type II cytokines such as IL-4 impair host defense against an intracellular fungal pathogen by amplifying macrophage generation of IL-33.

A

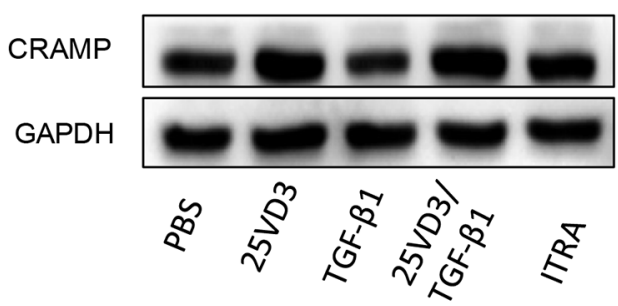

B

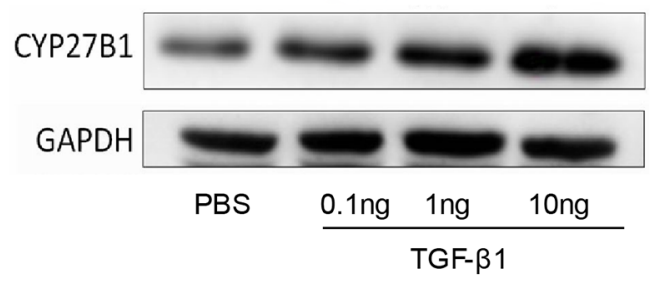

C

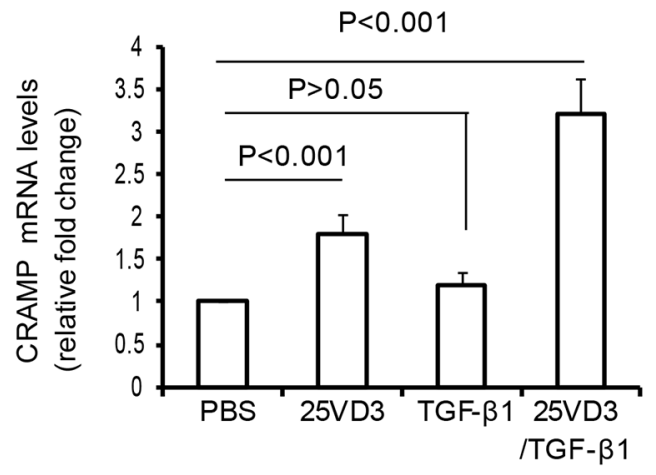

IFN- $\gamma$ treatment of human macrophages did not demonstrate antimicrobial activity against intracellular M. tuberculosis. Vitamin D is required for IFN- $\gamma$-mediated antimicrobial activity of human macrophages [32]. In our present study, we first demonstrated that HDM-specific immunotherapy ameliorated pulmonary infection inflammatory response and inflammatory cells infiltration after HDM-challenged mice exposure to $P$. aeruginosa. HDM-immunotherapy mice significantly reduced lung inflammation, bacterial load and rectal temperature. Therefore, SIT with HDM can indeed enhance host defense to resist respiratory tract infection (Figure 5).
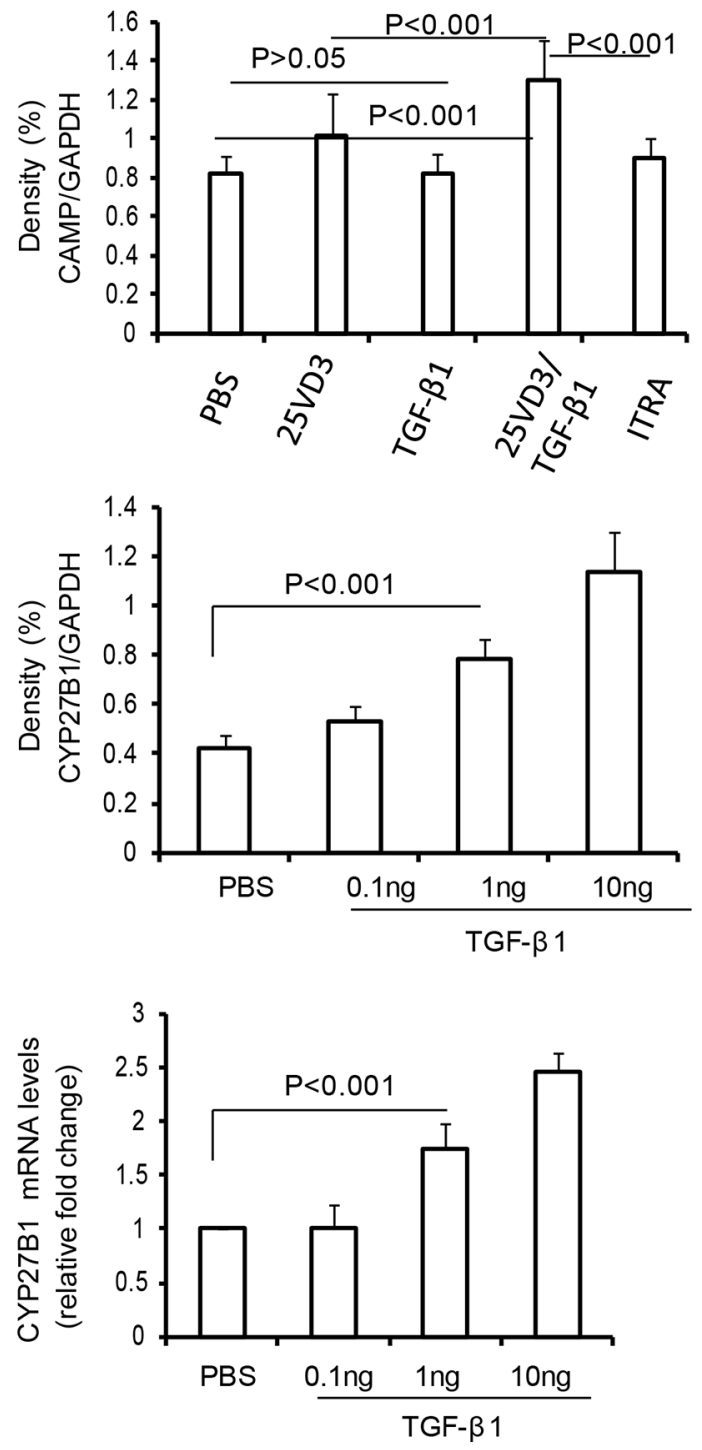

Figure 7: TGF- $\beta 1$ increases CRAMP depending CYP27B1 in 16HBE cells. (A) Western blot analysis of CRAMP with 16HBE cells exposed to TGF- $\beta 1,25 \mathrm{VD}_{3}$, TGF- $\beta 1 / 25 \mathrm{VD}_{3}$ and ITRA/ TGF- $\beta 1 / 25 \mathrm{VD}_{3}$ Relative density (change) of CRAMP in cells. $\beta$-actin was used as loading control. (B) Western blot analysis of CYP27B1 in 16HBE cells exposed to TGF- $\beta 1$. Relative density (change) of CRAMP in cells. $\beta$-actin was used as loading control. The mRNA expression of CRAMP (C) and CYP27B1 (D) was determined in cells using Realtime-PCR. Results are representative of three experiments and data are shown as means \pm SDEV. One-way ANOVA for group comparisons. Significant differences in the mean values were defined as $\mathrm{p}<0.05$. 
Vitamin D3 has been identified to be an inducing factor of cathelicidin $[8,33,34]$. It has been confirmed that the promoter region of cathelicidin has a vitamin $\mathrm{D}$ response element (VDRE) sequence. Lower expression of the VDR or vitamin D3 deficiency impaired immune response [35, 36]. CYP27B1 hydroxylase enzyme is responsible for the conversion of the inactive vitamin D3 $\left(25 \mathrm{VD}_{3}\right)$ preform to the active form $\left(1,25 \mathrm{VD}_{3}\right)$ [37]. Our data showed that the expression of CYP27B1 protein in lungs was inhibited in HDM-induced airway inflammation mice. HDM-specific immunotherapy predominantly increased the expression of CYP27B1 protein in lungs (Figure 4).

HDM-specific immunotherapy predominantly increased the level of TGF- $\beta 1$ in HDM-induced airway inflammation (Figure 3). However, no previous study had linked TGF- $\beta 1$ to host defense against bacteria via alpha-hydroxylase, but available databases led us to consider this possibility $[32,38]$. We evaluated the relevance of TGF- $\beta 1$ and defense against bacteria in vitro. Our findings demonstrated that TGF- $\beta 1$ did not directly increase CRAMP expression. Meanwhile, TGF- $\beta 1$ can induce CYP27B1 in a dose dependent manner. CYP27B1 blocker itraconazole suppressed TGF- $\beta$-induced cathelicidin. Furthermore, we next investigated the effect of TGF- $\beta 1$ induced CYP27B1 in defense against bacteria in airway cells. Our studies exhibited that TGF- $\beta 1 / 25 \mathrm{VD}_{3}$ significantly decreased the levels of CFUs in $16 \mathrm{HBE}$ exposes to $P$. aeruginosa. ITRA significantly increased the level of CFUs compared to TGF- $\beta 1 / 25 \mathrm{VD}_{3}$-treated $16 \mathrm{HBE}$ cells. We report for the first time that allergenspecific immunotherapy enhances defense against bacteria via TGF- $\beta 1$ induced CYP27B1 during allergic airway inflammation.

In conclusion, we have found that HDMimmunotherapy decreased HDM-induce airway inflammation and increased the expression of CRAMP and CYP27B1 expression in mice. We further showed that HDMimmunotherapy enhanced defense against bacteria during HDM-challenged mice exposure to $P$. Aeruginosa. We have identified a critical role of CYP27B1 in TGF- $\beta 1$-induced CRAMP expression in $16 \mathrm{HBE}$ cells. This study indicates that HDM-immunotherapy increased defense against $P$.

A

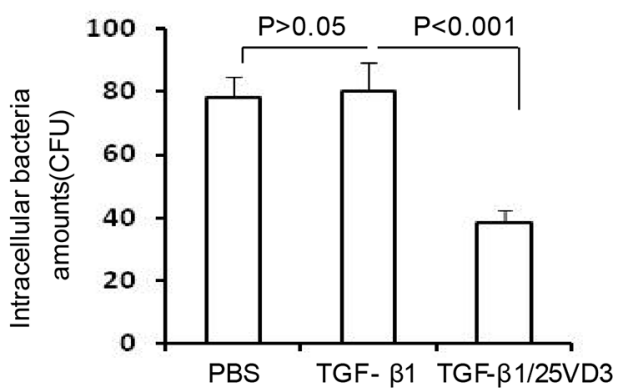

B

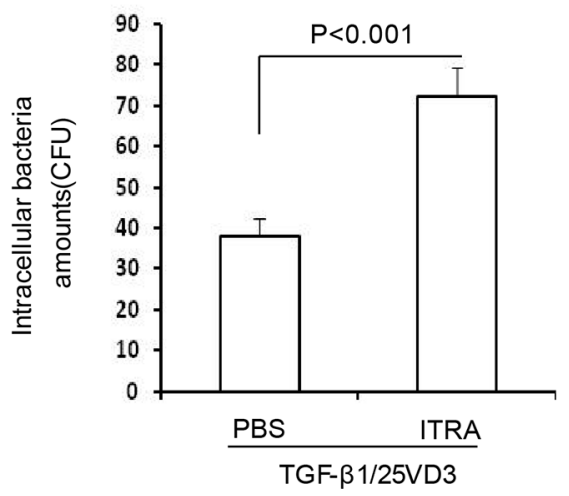

C

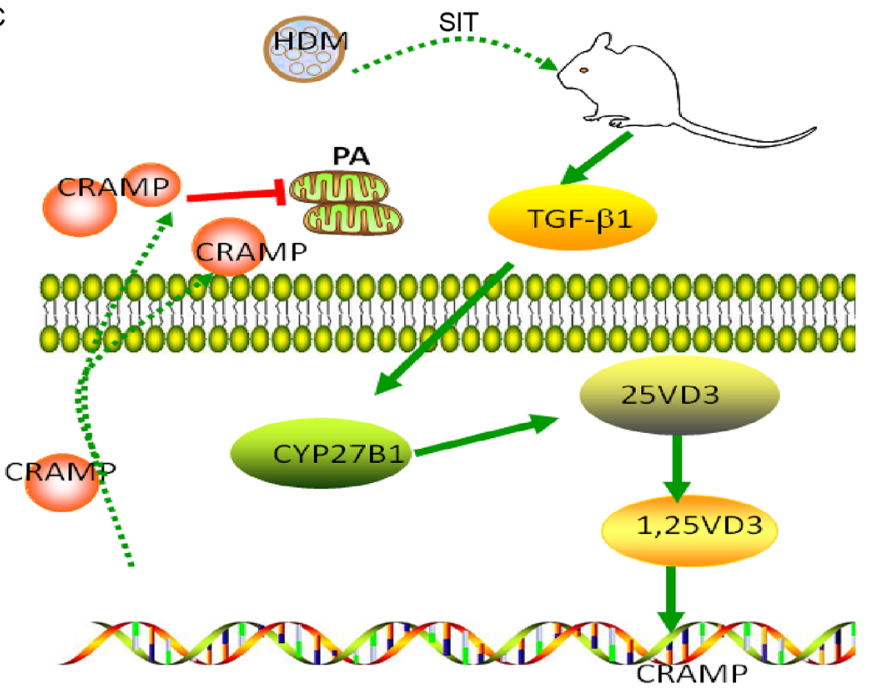

Figure 8: TGF- $\beta 1$ increases defense against bacteria by CYP27B1-dependent activation. (A) 16HBE cells were pretreated with TGF- $\beta 1$ and TGF- $\beta 1 / 25 \mathrm{VD}_{3}$. (B) $16 \mathrm{HBE}$ cells were pretreated with ITRA. The cells infected with $P$. aeruginosa cells were lysed and plated to confirm the presence of intracellular bacteria. Results are representative of three experiments and data are shown as means \pm SDEV. One-way ANOVA for group comparisons. Significant differences in the mean values were defined as $p<0.05$. (C) Schematic representation of TGF- $\beta 1$ induced CYP27B1 role in HDM immunotherapy increasing defense against $P$. aeruginosa during allergic airway inflammation. 
aeruginosa, leading to TGF- $\beta 1$-induced CRAMP expression via CYP27B1.

\section{MATERIALS AND METHODS}

\section{Reagents}

The CRAMP antibody(IF) (ab180760) was purchased from Abcam (Cambridge, MA, USA). The CYP27b1 antibody (sc-67261) was purchased from Santa Cruz Biotechnology (Dallas, Texas, USA). The CRAMP antibody(WB) (PAB13021) was purchased from Abnova (Taipei, Taiwan). The GAPDH antibody (Cat. No.\#2118) was purchased from Cell Signaling (Danvers, MA, USA). The ELISA kits of IL-4, IL-10, IFN-gamma, and TGF- $\beta 1$ were purchased from eBioscience (San Diego, CA, USA), and the ELISA kit of CRAMP was purchased from CUSABIO (Wuhan, China). The recombinant human cytokine proteins (TGF- $\beta 1$, IFN- $\gamma$, and IL-10) were purchased from PeproTech (Rocky Hill, NJ, USA). 25 VD3, 1,25 VD3, and polymyxin B were purchased from Sigma-Aldrich(St. Louis, MO, USA). Itraconazole was purchase from Janssen (Beerse, Belgium). HDM extracts (Der $f$ allergen) were provided by State Key Laboratory of Respiratory Disease for Allergy at Shenzhen University (Shenzhen, China)

\section{Immunotherapy protocol}

Female BALB/c mice (4 to 6 weeks) were purchased from Guangdong Experimental Animal Center. They were maintained under specific pathogen-free conditions in the Animal Experimental Center of Shenzhen University (Shenzhen, China). All animal experiments were performed in accordance with the guidelines of the Animal Experiments Center of Shenzhen University. All experimental protocols were approved by and performed in accordance with the Medical Ethics Committee in Medical Center of Shenzhen University and the National Institute of Health guidelines on the care and use of animals. BALB/c mice were sensitized with intraperitoneal injection $100 \mu \mathrm{g}$ of house dust mites extracts (HDM) and $2 \mathrm{mg}$ of aluminum hydroxide on days 0,7 and 14. For SIT treatment mice, HDM-treated mice were immunized with subcutaneous injection $100 \mu \mathrm{g}$ of HDM once every other day for 8 times on day 28. Meanwhile, HDM-exposed and phosphate buffered saline (PBS) control mice were immunized with subcutaneous injection of PBS. The mice were challenged with an intranasal instillation of $50 \mu \mathrm{g}$ of HDM in $50 \mu \mathrm{l}$ of PBS 7 times/week. Control mice were given $\mathrm{PBS}$ alone.

\section{Airway responsiveness}

AHR was measured with Buxco whole-body plethysmography (WBP) system (Buxco Research
Company, United States) in response to inhaled methacholine (acetyl- $\beta$-methyl-choline chloride, Sigma, The Netherlands). After the last challenge, mice were monitored for about 10 minutes in the chamber until their breathing went stable. After 5 minutes baseline was recorded, the responses were assessed for 5 minutes after inhaling different concentration of atomized methacholine solutions $(0,6.25,12.5,25,50$, and $100 \mathrm{mg} / \mathrm{ml})$ respectively. About 5 minute intervals were given between tests to allow the respiratory intensity to return to the baseline. AHR was expressed as enhanced pause (Penh) as described in detail previously [39].

\section{Bacteria preparation}

The Pseudomonas aeruginosa strain 103 (P.a.) was provided by the clinical laboratory of the first affiliate hospital of Shenzhen University. Bacteria were cultured for about 16 hours in LB medium at $37^{\circ} \mathrm{C}$ with shaking in $150 \mathrm{rpm}$, and incubated the bacteria for about 1 hour until the mid-log phase in $10 \mathrm{ml}$ fresh LB broth. Optical density (OD) was measured at $600 \mathrm{~nm}$. The bacteria were pelleted by centrifugation at $2000 \times \mathrm{g}$ for 5 minutes at $4^{\circ} \mathrm{C}$. The density was adjusted to $0.1 \mathrm{OD}\left(0.1 \mathrm{OD}=1 \times 10^{8} \mathrm{CFUs}\right)$ in sterile PBS.

\section{Acute $P$. aeruginosa infection model}

To estimate the severity of pneumonia infected with an intranasal instillation with P.a, BALB/c mice were randomly divided into 4 groups $(n=6)$. The Naïve group and the P.a. group were sensitized, treated, and challenged with PBS. Other mice were sensitized by intraperitoneal (i.p.) injection with $100 \mu \mathrm{g}$ HDM absorbed to $2 \mathrm{mg} \mathrm{Al}$ $(\mathrm{OH}) 3$ on day 0,7 and 14 . From day 28, mice were received subcutaneous (s.c.) injection (every 2 days, 8 administrations) with PBS (HDM/P.a. group) or $100 \mu \mathrm{g}$ HDM (SIT/P.a. group), respectively. The challenge was initiated seven days after the final immunization. Mice were challenged with intranasal (i.n.) instillation of $50 \mu \mathrm{g}$ HDM daily for 7 days. Twenty-four hours after the last challenge, mice in the P.a. group, the HDM/P.a. group, and the SIT/P.a. group were anesthetized using diethyl ether and were then infected with an intranasal instillation $1 \times 10^{7}$ CFUs P.a.[6]. The Naïve group mice instilled with equivalent doses of PBS. The rectal temperature of mice was measured 24 hours after infection, and then mice were euthanized.

\section{Measurement of rectal temperature}

Rectal temperature was measured using a $1.5-\mathrm{cm}$ thermistor probe. After inserted the probe into the rectum of mice, temperatures were recorded when the probe reading stabilized. Each mouse was triple measured to avoid deviations. 


\section{Histological evaluation}

The mice were sacrificed. The cells in the BAL fluid were fixed and stained differential cell counts were performed in duplicate on coded slides for 200 cells from each sample as described previously [39]. The lung tissues were fixed in 10\% neutral-buffered formalin and embedded in paraffin. Lung sections were stained with standard hematoxylin-eosin staining (H\&E) methods to evaluate the tissue inflammation. The degree of cellular infiltration was scored using previously described methods [40]. A score ranging from 0 to 3 was applied to each observed bronchus, with approximately 10 areas total scored.

\section{Cytokine assays and HDM specific antibodies levels in sera}

The levels of L-4, IL-10, TGF- $\beta 1$ and IFN- $\gamma$ in BALF were measured by sandwich enzyme-linked immunosorbent assay (ELISA) with commercial reagent kits (eBbioscience, USA) in accordance with the manufacturer's instructions. HDM-specific IgE, IgG1 and IgG2a antibodies were measured by indirect ELISA [41]. Briefly, the plates were coated with $100 \mathrm{ng}$ HDM per wells in carbonate buffered solution at $4^{\circ} \mathrm{C}$ for overnight, blocked at room temperature for 1 hour, and added $100 \mu \mathrm{l}$ serum to each well for $2 \mathrm{~h}$. Peroxidase-labeled goat anti-human IgE, IgG1 and IgG2a were added to each well for $1 \mathrm{~h}$, and then added $100 \mu \mathrm{l} /$ well tetramethylbenzidine (TMB) to develop. After stopped by $2 \mathrm{M} \mathrm{H}_{2} \mathrm{SO}_{4}(50 \mu \mathrm{l} /$ well $)$, the results were measured by ELx808 absorbance microplate reader (BioTek, Shanghai, China) at $450 \mathrm{~nm}$.

\section{Evaluation of bacteria in BAL fluid}

After BAL fluid were centrifuged $(500 \times \mathrm{g}$ for $5 \mathrm{~min}$ at $4{ }^{\circ} \mathrm{C}$ ), the precipitate was resuspended and dropped on slides followed by staining with a Gram's method. The slides were evaluated for bacteria infiltration under a light microscope.

\section{Quantitation of bacteria in lung}

The lungs were removed, weighed, and homogenized in sterile-PBS in aseptic conditions, and aliquots were plated on $P$. aeruginosa-selective plates. Bacterial colonies were counted after incubation at $37^{\circ} \mathrm{C}$ for 24 hours.

\section{Cell lines}

The SV40-transformed human bronchial epithelial cell line 16HBE14o-was obtained from Xiangya Central Experiment Laboratory (Xiangya School of Medicine, CSU, Changsha, Hunan, China). Cells were cultured in Dulbecco's modified eagle medium (DMEM; Gibco, Thermo Fisher Scientific) supplemented with 10\% heat- inactivated fetal bovine serum (FBS; Gibco, Thermo Fisher Scientific), $2 \mathrm{mM}$ L-glutamine (Gibco, Thermo Fisher Scientific), $100 \mathrm{U} / \mathrm{mL}$ penicillin (Gibco, Thermo Fisher Scientific), and $100 \mu \mathrm{g} / \mathrm{mL}$ streptomycin (Gibco, Thermo Fisher Scientific). 16HBE14o- cells were grown to $85-90 \%$ confluence and were serum deprived for 18 to 24 hours before treatments.

\section{Epithelial cell culture}

To observe the expression of CRAMP in epithelial cells, $16 \mathrm{HBE} 14 \mathrm{o}-$ cells were plated to culture dishes, and were allowed to adhere at $37^{\circ} \mathrm{C}$ under $5 \% \mathrm{CO} 2$ in electronic controlled incubator (Thermo Forma, USA). After an initial study with TGF- $\beta_{1}(1 \mathrm{ng} / \mathrm{ml})$, IFN- $\gamma(200 \mathrm{IU})$, and IL-10 $(50 \mathrm{ng} / \mathrm{ml})$, we found that treatment of cytokines cannot increase the expression of CRAMP in 16HBE14ocells. In subsequent experiments, the cells were treated with $25 \mathrm{VD}_{3}(10 \mathrm{nM})$, TGF $-\beta_{1}(1 \mathrm{ng} / \mathrm{ml})+25 \mathrm{VD} 3(10 \mathrm{nM})$, IFN- $\gamma(200 \mathrm{IU})+25 \mathrm{VD} 3(10 \mathrm{nM})$, IL-10(50ng/ml $)+25 \mathrm{VD} 3$ $(10 \mathrm{nM})$, and $1,25 \mathrm{VD}_{3}(10 \mathrm{nM})$ in serum-free culture medium for $24 \mathrm{~h}$. To evaluate the expression of CYP27b1 in $16 \mathrm{HBE} 14 \mathrm{o}-$ cells. We stimulated the cells with TGF- $\beta_{1}$ in different doses $(0.1 \mathrm{ng} / \mathrm{ml}, 1 \mathrm{ng} / \mathrm{ml}$, and $10 \mathrm{ng} / \mathrm{ml})$ for 24 hours.

\section{Inhibition of CYP27b1}

16HBE14o- cells were prepared as described above and pre-treated with itraconazole $\left(10^{-7} \mathrm{M}\right)$, a specific inhibitor of CYP27b1, for 2 hours, and then stimulated with TGF- $\beta_{1}(1 \mathrm{ng} / \mathrm{ml})+25 \mathrm{VD} 3(10 \mathrm{nM})$ for $24 \mathrm{~h}$. CRAMP levels in cells were determined.

\section{Cell infection experiments}

16HBE14o-cells were changed to antibioticfree medium. Cells were treated with $25 \mathrm{VD}_{3}(10 \mathrm{nM})$, TGF- $\beta 1(1 \mathrm{ng} / \mathrm{ml}), \quad$ TGF $-\beta_{1}(1 \mathrm{ng} / \mathrm{ml})+25 \mathrm{VD} 3(10 \mathrm{nM}), 25$ VD3(10nM)+ITRA(pretreated with ITRA for $2 \mathrm{~h}$ ), TGF$\beta 1(1 \mathrm{ng} / \mathrm{ml})+25 \mathrm{VD} 3(10 \mathrm{nM})+$ ITRA(pretreated with ITRA for $2 \mathrm{~h}$ ) for 48 hours at $37^{\circ} \mathrm{C}$. And parts of cells were only treated with ITRA for $2 \mathrm{~h}$ for control. Then cells were infected by $P$. aeruginosa in an MOI of 10:1 bacteriacell ratio. After incubation for 1 hour, the cells were washed with PBS twice and incubated with fresh medium containing polymyxin $100 \mu \mathrm{g} \mathrm{ml}^{-1}$ to kill extracellular bacteria. After 1 hour, samples were plated in LB solid culture medium to confirm that the extracellular bacteria had been killed. The cells were then homogenized with PBS and spread on LB plates. Bacterial colonies were counted after incubation at $37^{\circ} \mathrm{C}$ for 24 hours.

\section{Real-time RT-PCR}

Total RNA was extracted from lung tissue or cell lysate with TRIzol Reagent (Invitrogen, Thermo Scientific, 
USA) as recommended by the manufacturer. A total of $1.5 \mu \mathrm{g}$ of total RNA preparation was reverse transcribed using a cDNA synthesis kit (RevertAid First Strand cDNA Synthesis Kit, Thermo Scientific, USA). cDNA was diluted $1 / 5$, and $5 \mu \mathrm{l}$ was used as template in a $50 \mu \mathrm{l}$ SYBR-Green PCR reaction system, according to the manufacturer's instruction (iQ ${ }^{\mathrm{TM}}$ SYBR ${ }^{\circledR}$ Green, Bio-Rad, USA). $\beta$-actin premier(sense, 5'-CATCCGTAAAGACCTCTATGCCA AC-3'; antisense, 5'-ATGGAGCCACCGATCCACA-3'), GAPDH primer(sense, 5'-GGAGTCAACG GATTTGGT CGTA-3'; antisense, 5'-GCAACAATATCCACTTTACC AGAGTTAA-3'), CRAMP primer(Mus musculus) (sense, 5'-GTCTTGGGAACCATGCAGTT-3'; antisense, 5'TGGTTGAAGTCATCCACAGC-3'), CRAMP primer (Homo sapiens) (sense, 5'-GTCACCAGAGGAT TGTGACTTCAA-3'; antisense, 5'-TTGAGGGTCA CTGTCCCCATA-3'), and CYP27b1 primer(sense, 5'-GTTTGTGTCCACGCTG-3'; antisense, 5'-CCCGC CAATAGCAACT-3') were synthesized by Sangon Biotech(Shanghai, China). Specificity of RT-PCR was controlled by omission of the template or the reverse transcription. Quantitative PCR results were obtained using the $2-\Delta \Delta \mathrm{Ct}$ method and were normalized to $\beta$-actin or GAPDH.

\section{Immunofluorescent staining}

Frozen lung tissues at $-80^{\circ} \mathrm{C}$ were sectioned, and were fixed in acetone and blocked at room temperature. Sections were incubated with CRAMP antibody. A mouse isotype serum instead of the primary Abs was used as a negative control. FITC-conjugated goat antirabbit Ab(Cat. No.4030-02, SouthernBiotech, USA) as secondary Abs were used to probe the primary Abs. The cell nucleus was stained with PI (Sigma-Aldrich, USA). Tissue sections were viewed with an Olympus BX51 fluorescence microscope (Japan).

\section{Western blotting}

The cells were homogenized with lysis buffer (1000 $\mu$ l RIPA with $10 \mu$ phenylmethanesulfonyl fluoride (PMSF), Beyotime, China) in ice bath. Protein assay was performed using a bicinchoninic acid (BCA) concentration measurement kit (Solarbio, China) to ensure each sample contained equal amounts of protein. Proteins $(20 \mu \mathrm{g} /$ lane) were loaded and then run on $10 \%$ sodium dodecyl sulfate-polyacrylamide gel electrophoresis (SDS-PAGE) at $100 \mathrm{~V}$ for $90 \mathrm{~min}$. Dissolved proteins were transferred onto a nitrocellulose membrane by electroblotting with Bio-Rad blotting transfer unit(Bio-Rad, USA) at $300 \mathrm{~mA}$ for $45 \mathrm{~min}$ in ice bath. Non-specific binding sites were blocked with $5 \%$ skim milk at room temperature for 2 hours. The membranes was incubated overnight at $4^{\circ} \mathrm{C}$ with rabbit polyclonal antibody against CRAMP (1:1000 diluted with 1\% skim milk, PAB13021, Abnova,
Taipei), or rabbit polyclonal antibody against CYP27b1 (1:200 diluted with 1\% skim milk, sc-67261, Santa Cruz Biotechnology, USA), or rabbit monoclonal antibody against GAPDH (1:1000 diluted with 1\% skim milk, Cat. No. 2118, Cell Signaling, USA). After washed three times in TBST for 10 min each, the membranes were then incubated with HRP-conjugated goat anti-rabbit antibody (1:10000 dilution, EarthOx, Millbrae, California, USA) at $37^{\circ} \mathrm{C}$ for 1 hour and washed five times for 10 minutes each with TBST, and then three times for with TBS for 5 minutes each. Chemiluminescent substrate (Bio-Rad's Clarity ECL Western Blotting Substrate) was added to expose strips. Strips were semiquantitative analyzed with the Image J $1.48 \mathrm{~V}$ software.

\section{Immunohistochemistry}

Paraffin sections of lung tissue were deparaffinized and rehydrated. Antigen retrieval was performed with high pressure method in citrate $(\mathrm{pH}=6.0)$ for 3 minutes. Normal goat serum was added to block non-specific binding sites at $37^{\circ} \mathrm{C}$ for 40 minutes. The sections were incubated with rabbit polyclonal antibody against CYP27b1 (1:100 dilution, sc-67261, Santa Cruz Biotechnology, USA) overnight at $4^{\circ} \mathrm{C}$. The secondary antibody working solution (Boster, Wuhan, China) was incubated at $37^{\circ} \mathrm{C}$ for $40 \mathrm{~min}$. After rinsed with $\mathrm{PBS}$, $\mathrm{SABC}$ was then incubated for 30 minutes at $37^{\circ} \mathrm{C}$. Finally, the slides were visualized using DAB immunostaining under a light microscope.

\section{Statistical analysis}

Data are presented as mean \pm SDEV. Statistical analysis was performed using Student's t test for comparing two groups and one-way ANOVA for multiple group comparisons. Significant differences in the mean values were defined as $\mathrm{p}<0.05$. All statistical analyses were done with SPSS 19.0 software.

\section{Author contributions}

Conceived and designed the study: Guoping Li, Min Wu and Zhigang Liu. Performed the experiments: Xiaoyu Liu, Junyi Wang, Hui Wang, Xiefang Yuan, Yin Li. Analyzed the data: Junyi Wang, Hui Wang. Wrote the paper: Guoping Li, Yin Li. All authors read and approved the final manuscript.

\section{ACKNOWLEDGMENTS}

This study was supported by grants from the National Natural Science Foundation of China (No. 81170032, 91542104, 91442118, 31328014 and 31400786), Luzhou government and Southwest Medical University Cooperative Project (No.2016lzxnyd-z01) 


\section{CONFLICTS OF INTEREST}

The authors declare no conflicts of interest.

\section{REFERENCES}

1. Larsen JN, Broge L, Jacobi H. Allergy immunotherapy: the future of allergy treatment. Drug Discov Today. 2016; 21: 26-37. https://doi.org/10.1016/j.drudis.2015.07.010.

2. Green BJ, Wiriyachaiporn S, Grainge C, Rogers GB, Kehagia V, Lau L, Carroll MP, Bruce KD, Howarth PH. Potentially pathogenic airway bacteria and neutrophilic inflammation in treatment resistant severe asthma. PLoS One. 2014; 9: e100645. https://doi.org/10.1371/journal. pone. 0100645 .

3. Beisswenger C, Kandler K, Hess C, Garn H, Felgentreff K, Wegmann M, Renz H, Vogelmeier C, Bals R. Allergic airway inflammation inhibits pulmonary antibacterial host defense. J Immunol. 2006; 177: 1833-7.

4. Gillissen A, Paparoupa M. Inflammation and infections in asthma. Clin Respir J. 2015; 9: 257-69. https://doi. org/10.1111/crj.12135.

5. Zhang L, Prietsch SO, Mendes AP, Von Groll A, Rocha GP, Carrion L, Da Silva PE. Inhaled corticosteroids increase the risk of oropharyngeal colonization by Streptococcus pneumoniae in children with asthma. Respirology. 2013; 18: 272-7. https://doi.org/10.1111/j.1440-1843.2012.02280.x.

6. Wang P, Wang X, Yang X, Liu Z, Wu M, Li G. Budesonide suppresses pulmonary antibacterial host defense by down-regulating cathelicidin-related antimicrobial peptide in allergic inflammation mice and in lung epithelial cells. BMC Immunol. 2013; 14: 7. https://doi. org/10.1186/1471-2172-14-7.

7. Lan N, Luo G, Yang X, Cheng Y, Zhang Y, Wang X, Wang X, Xie T, Li G, Liu Z, Zhong N. 25-Hydroxyvitamin D3-deficiency enhances oxidative stress and corticosteroid resistance in severe asthma exacerbation. PLoS One. 2014; 9: e111599. https://doi.org/10.1371/journal.pone.0111599.

8. Vandamme D, Landuyt B, Luyten W, Schoofs L. A comprehensive summary of LL-37, the factotum human cathelicidin peptide. Cell Immunol. 2012; 280: 22-35. https://doi.org/10.1016/j.cellimm.2012.11.009.

9. Hewison M. Vitamin D and the intracrinology of innate immunity. Mol Cell Endocrinol. 2010; 321: 103-11. https:// doi.org/10.1016/j.mce.2010.02.013.

10. Chun RF, Liu NQ, Lee T, Schall JI, Denburg MR, Rutstein RM, Adams JS, Zemel BS, Stallings VA, Hewison M. Vitamin D supplementation and antibacterial immune responses in adolescents and young adults with HIV/AIDS. J Steroid Biochem Mol Biol. 2015; 148: 290-7. https://doi. org/10.1016/j.jsbmb.2014.07.013.

11. Calderon MA, Linneberg A, Kleine-Tebbe J, De Blay F, Hernandez Fernandez de Rojas D, Virchow JC, Demoly P. Respiratory allergy caused by house dust mites: what do we really know? J Allergy Clin Immunol. 2015; 136: 38-48. https://doi.org/10.1016/j.jaci.2014.10.012.

12. Yu HQ, Li XH, Guo H, Liu ZG, Ran PX, Ji KM, Wang J. Sublingual immunotherapy efficacy of Dermatophagoides farinae vaccine in a murine asthma model. Int Arch Allergy Immunol. 2010; 152: 41-8. https://doi. org/10.1159/000260082.

13. Skelding KA, Hickey DK, Horvat JC, Bao S, Roberts KG, Finnie JM, Hansbro PM, Beagley KW. Comparison of intranasal and transcutaneous immunization for induction of protective immunity against Chlamydia muridarum respiratory tract infection. Vaccine. 2006; 24: 355-66. https://doi.org/10.1016/j.vaccine.2005.07.104.

14. van der Valk JP, de Jong NW, Gerth van Wijk R. Review on immunotherapy in airway allergen sensitised patients. Neth J Med. 2015; 73: 263-9.

15. Navarro S, Lazzari A, Kanda A, Fleury S, Dombrowicz D, Glaichenhaus N, Julia V. Bystander immunotherapy as a strategy to control allergen-driven airway inflammation. Mucosal Immunol. 2015; 8: 841-51. https://doi.org/10.1038/ mi.2014.115.

16. Bogefors J, Kvarnhammar AM, Cardell LO. Upregulated levels of human $\beta$-defensins in patients with seasonal allergic rhinitis after allergen-specific immunotherapy treatment. Int Forum Allergy Rhinol. 2013; 3: 99-103. https://doi.org/10.1002/alr.21127.

17. Bogefors J, Kvarnhammar AM, Millrud CR, Georen SK, Cardell LO. LEAP-2, LL-37 and RNase7 in tonsillar tissue: downregulated expression in seasonal allergic rhinitis. Pathog Dis. 2014; 72: 55-60. https://doi. org/10.1111/2049-632X.12183.

18. Bohm L, Maxeiner J, Meyer-Martin H, Reuter S, Finotto S, Klein M, Schild H, Schmitt E, Bopp T, Taube C. IL-10 and regulatory $\mathrm{T}$ cells cooperate in allergenspecific immunotherapy to ameliorate allergic asthma. J Immunol. 2015; 194: 887-97. https://doi.org/10.4049/ jimmunol.1401612.

19. Palomares O, Martin-Fontecha M, Lauener R, TraidlHoffmann C, Cavkaytar O, Akdis M, Akdis CA. Regulatory $\mathrm{T}$ cells and immune regulation of allergic diseases: roles of IL-10 and TGF- $\beta$. Genes Immun. 2014; 15: 511-20. https:// doi.org/10.1038/gene.2014.45.

20. Lauter K, Arnold A. Analysis of CYP27B1, encoding 25-hydroxyvitamin D-1alpha-hydroxylase, as a candidate tumor suppressor gene in primary and severe secondary/ tertiary hyperparathyroidism. J Bone Miner Res. 2009; 24 : 102-4. https://doi.org/10.1359/jbmr.080903.

21. Maazi H, Shirinbak S, Willart M, Hammad HM, Cabanski M, Boon L, Ganesh V, Baru AM, Hansen G, Lambrecht BN, Sparwasser T, Nawijn MC, van Oosterhout AJ. Contribution of regulatory $\mathrm{T}$ cells to alleviation of experimental allergic asthma after specific immunotherapy. Clin Exp Allergy. 2012; 42: 1519-28. https://doi. org/10.1111/j.1365-2222.2012.04064.x. 
22. Yang G, Geng XR, Song JP, Wu Y, Yan H, Zhan Z, Yang L, He W, Liu ZQ, Qiu S, Liu Z, Yang PC. Insulin-like growth factor 2 enhances regulatory T-cell functions and suppresses food allergy in an experimental model. J Allergy Clin Immunol. 2014; 133: 1702-8.e5. https://doi.org/10.1016/j. jaci.2014.02.019.

23. Werner JL, Steele C. Innate receptors and cellular defense against pulmonary infections. J Immunol. 2014; 193: 384250. https://doi.org/10.4049/jimmunol.1400978.

24. Tecle T, Tripathi S, Hartshorn KL. Review: defensins and cathelicidins in lung immunity. Innate Immun. 2010; 16: 151-9. https://doi.org/10.1177/1753425910365734.

25. Kahlenberg JM, Kaplan MJ. Little peptide, big effects: the role of LL-37 in inflammation and autoimmune disease. J Immunol. 2013; 191: 4895-901. https://doi.org/10.4049/ jimmunol.1302005.

26. Lecaille F, Lalmanach G, Andrault PM. Antimicrobial proteins and peptides in human lung diseases: A friend and foe partnership with host proteases. Biochimie. 2015; 122: 151-68. https://doi.org/10.1016/j.biochi.2015.08.014.

27. Bisgaard $\mathrm{H}$, Hermansen $\mathrm{MN}$, Buchvald $\mathrm{F}$, Loland L, Halkjaer LB, Bonnelykke K, Brasholt M, Heltberg A, Vissing NH, Thorsen SV, Stage M, Pipper CB. Childhood asthma after bacterial colonization of the airway in neonates. N Engl J Med. 2007; 357: 1487-95. https://doi. org/10.1056/NEJMoa052632.

28. Verma A, Kroetz DN, Tweedle JL, Deepe GS Jr. Type II cytokines impair host defense against an intracellular fungal pathogen by amplifying macrophage generation of IL-33. Mucosal Immunol. 2015; 8: 380-9. https://doi.org/10.1038/ mi.2014.75.

29. Howell MD, Novak N, Bieber T, Pastore S, Girolomoni G, Boguniewicz M, Streib J, Wong C, Gallo RL, Leung DY. Interleukin-10 downregulates antimicrobial peptide expression in atopic dermatitis. J Invest Dermatol. 2005; 125: 738-45. https://doi. org/10.1111/j.0022-202X.2005.23776.X.

30. Li C, Li H, Jiang Z, Zhang T, Wang Y, Li Z, Wu Y, Ji S, Xiao S, Ryffel B, Radek KA, Xia Z, Lai Y. Interleukin-33 increases antibacterial defense by activation of inducible nitric oxide synthase in skin. PLoS Pathog. 2014; 10: e1003918. https://doi.org/10.1371/journal.ppat.1003918.

31. McAleer JP, Kolls JK. Directing traffic: IL-17 and IL-22 coordinate pulmonary immune defense. Immunol Rev. 2014; 260: 129-44. https://doi.org/10.1111/imr.12183.

32. Fabri M, Stenger S, Shin DM, Yuk JM, Liu PT, Realegeno S, Lee HM, Krutzik SR, Schenk M, Sieling PA, Teles $\mathrm{R}$, Montoya D, Iyer SS, et al. Vitamin D is required for
IFN-gamma-mediated antimicrobial activity of human macrophages. Sci Transl Med. 2011; 3: 104ra2. https://doi. org/10.1126/scitranslmed.3003045.

33. Schauber J, Dorschner RA, Yamasaki K, Brouha B, Gallo RL. Control of the innate epithelial antimicrobial response is cell-type specific and dependent on relevant microenvironmental stimuli. Immunology. 2006; 118: 50919. https://doi.org/10.1111/j.1365-2567.2006.02399.x.

34. Schauber J, Dorschner RA, Coda AB, Buchau AS, Liu PT, Kiken D, Helfrich YR, Kang S, Elalieh HZ, Steinmeyer A, Zugel U, Bikle DD, Modlin RL, et al. Injury enhances TLR2 function and antimicrobial peptide expression through a vitamin D-dependent mechanism. J Clin Invest. 2007; 117: 803-11. https://doi.org/10.1172/JCI30142.

35. Gombart AF, Borregaard N, Koeffler HP. Human cathelicidin antimicrobial peptide (CAMP) gene is a direct target of the vitamin D receptor and is strongly up-regulated in myeloid cells by 1,25-dihydroxyvitamin D3. FASEB J. 2005; 19: 1067-77. https://doi.org/10.1096/fj.04-3284com.

36. Gombart AF. The vitamin D-antimicrobial peptide pathway and its role in protection against infection. Future Microbiol. 2009; 4: 1151-65. https://doi.org/10.2217/fmb.09.87.

37. Liu PT, Stenger S, Li H, Wenzel L, Tan BH, Krutzik SR, Ochoa MT, Schauber J, Wu K, Meinken C, Kamen DL, Wagner M, Bals R, et al. Toll-like receptor triggering of a vitamin D-mediated human antimicrobial response. Science. 2006; 311: 1770-3. https://doi.org/10.1126/ science. 1123933 .

38. Lagishetty V, Chun RF, Liu NQ, Lisse TS, Adams JS, Hewison M. 1alpha-hydroxylase and innate immune responses to 25-hydroxyvitamin D in colonic cell lines. J Steroid Biochem Mol Biol. 2010; 121: 228-33. https://doi. org/10.1016/j.jsbmb.2010.02.004.

39. Xie T, Luo G, Zhang Y, Wang X, Wang X, Wu M, Li G. Rho-kinase inhibitor fasudil reduces allergic airway inflammation and mucus hypersecretion by regulating STAT6 and NFkappaB. Clin Exp Allergy. 2015; 45: 181222. https://doi.org/10.1111/cea.12606.

40. Li G, Fox J 3rd, Liu Z, Liu J, Gao GF, Jin Y, Gao H, Wu M. Lyn mitigates mouse airway remodeling by downregulating the TGF-beta3 isoform in house dust mite models. J Immunol. 2013; 191: 5359-70. https://doi.org/10.4049/ jimmunol.1301596.

41. Li GP, Liu ZG, Qiu J, Ran PX, Zhong NS. DNA vaccine encoding Der $\mathrm{p} 2$ allergen generates immunologic protection in recombinant Der $\mathrm{p} 2$ allergen-induced allergic airway inflammation mice model. Chin Med J (Engl). 2005; 118: $534-40$. 